\title{
Odpowiedzialność karna za utrudnianie i udaremnianie prowadzenia kontroli na gruncie ustawy o ochronie danych osobowych z dnia 10 maja 2018 r. Podstawowe zagadnienia karnoprawne
}

\begin{abstract}
The paper analyses two provisions of the Act of 10 May 2018 on Personal Data Protection. It describes the structure and characteristic features of acts which obstruct or frustrate an inspection of compliance with personal data protection provisions. The paper emphasises the importance of powers held by a supervisory authority, the President of the Office for Personal Data Protection, especially in the context of the EU legislation. The article also gives examples of interrelationship between the controller and the entity that is controlled and discusses the way this impacts criminal liability. It presents a comparative analysis of the said provision alongside its analogous provision which is related to inspection carried out under Article 55 of the Act of 14 December 2018 on Personal Data Protection in Connection with Preventing and Fighting Crime. The final conclusions include some proposals for, inter alia, the analysis of problems noted by the Personal Data Protection Office while conducting control proceedings in the years 2018-2019.
\end{abstract}

Keywords: obstruction, frustration, inspection/control, accountability, RODO

Celem niniejszego artykułu jest zaprezentowanie refleksji dotyczących postępowania kontrolnego Prezesa Urzędu Ochrony Danych Osobowych [dalej jako: Prezes UODO]. Postępowanie to poprzedza wydanie przez ww. polski organ nadzoru decyzji administracyjnych, które nakładają na administratorów danych osobowych kary pieniężne za nieprzestrzeganie przepisów RODO ${ }^{1}$. Zakresem rozważań zostanie objęty przede wszystkim

${ }^{1}$ Rozporządzenie Parlamentu Europejskiego i Rady (UE) 2016/679 z dnia 27 kwietnia 2016 r. w sprawie ochrony osób fizycznych w związku z przetwarzaniem danych osobo- 
art. 108 Ustawy z dnia 10 maja 2018 r. o ochronie danych osobowych ${ }^{2}$ [dalej jako: Ustawa], który ma być gwarantem prawidłowego przebiegu postępowania kontrolnego. Na mocy powołanego przepisu bowiem utrudnianie lub udaremnianie kontroli podlega grzywnie, karze ograniczenia wolności albo pozbawienia wolności do lat $2^{3}$. Przepisy Ustawy odnoszące się do czynności kontrolnych Prezesa UODO stanowią wyraz generalnej idei ustawodawcy, która zakłada aktywną i rzetelną współpracę pomiędzy podmiotem kontrolującym a podmiotem kontrolowanym. W celu realizacji tego założenia przepisy Ustawy przyznały kontrolującemu szerokie uprawnienia oraz wprowadziły odpowiadające im obowiązki kontrolowanego.

Należy zwrócić uwagę, iż realizacja licznych obowiązków związanych z prowadzoną kontrolą może prowadzić do czasowej destabilizacji pracy kontrolowanego przedsiębiorstwa i wywierać negatywny wpływ na ogół prowadzonej przezeń działalności gospodarczej. Mając na uwadze uzasadniony interes kontrolowanego do minimalizacji wpływu kontroli na prowadzoną działalność, należy wyjaśnić, jakie zachowania mogą stanowić przestępstwo utrudniania lub udaremniania kontroli, a które z nich nie powinny pociągać konsekwencji karnych. W związku z powyższym niniejszy artykuł $\mathrm{w}$ głównej mierze zostanie poświęcony omówieniu przestępstwa z art. 108 Ustawy w kontekście uprawnień kontrolującego i odpowiadających im obowiązków kontrolowanego.

Dążąc do zwrócenia szerszej uwagi czytelnika na problematykę utrudniania i udaremniania kontroli, dodatkowym komentarzem zostanie opatrzony analogiczny do art. 108 Ustawy - przepis art. 55 Ustawy z dnia 14 grudnia 2018 r. o ochronie danych osobowych w związku z zapobieganiem i zwalczaniem przestępczości ${ }^{4}$. Przepis ten typizuje przestępstwo utrudniania lub istotnego utrudniania kontrolującemu przestrzegania przepisów o ochronie danych osobowych przetwarzanych w związku z zapobieganiem i zwalczaniem przestępczości. W dniu 6 lutego 2020 r. mija bowiem dokładnie rok od dnia wejścia w życie tej ustawy, która wdrożyła do polskiego porządku prawnego Dyrektywę Parlamentu Europejskiego i Rady (UE) 2016/680 z 27 kwietnia 2016 r. Ww. dyrektywa, określana często mianem „policyjnej”, reguluje sferę wyłączoną spod stosowania RODO. Oznacza to, że we wszystkich sprawach, w których

wych i w sprawie swobodnego przepływu takich danych oraz uchylenia dyrektywy 95/46/ WE (ogólne rozporządzenie o ochronie danych).

2 Dz.U. 2018, poz. 1000.

3 Art. 108 Ustawy jest pozakodeksowym przepisem prawa karnego, do którego zgodnie z brzmieniem art. 116 k.k. należy stosować wprost regulacje części ogólnej Kodeksu karnego, tj. od art. 1 do art. 115 k.k.

${ }^{4}$ Dz.U. 2019, poz. 125. 
przetwarzanie danych osobowych odbywa się m.in. w celu zapobiegania przestępczości, prowadzenia postępowań przygotowawczych, wykrywania i ścigania czynów zabronionych ${ }^{5}$, mają zastosowanie przepisy wdrażające dyrektywę. Natomiast w pozostałych sprawach stosuje się przepisy RODO. Porównanie tych dwóch - zdawałoby się analogicznych przepisów - jest istotne, ponieważ w zależności od obszaru przetwarzania danych podmioty mogą być zobowiązane do przestrzegania przepisów Ustawy z dnia 14 grudnia 2018 r. o ochronie danych osobowych przetwarzanych w związku z zapobieganiem i zwalczaniem przestępczości bądź RODO.

Przedstawiciele doktryny ${ }^{6}$ są zgodni w przedmiocie tego, że celem wprowadzenia obydwu powołanych przepisów ${ }^{7}$ było zapewnienie skuteczności dla całokształtu systemu ochrony danych osobowych oraz że mają one stanowić realizację nałożonego na państwa członkowskie w art. 63 dyrektywy 2016/680 obowiązku transpozycji jej przepisów do prawa krajowego.

Kontrolę, o której mowa w art. 55 Ustawy z dnia 14 grudnia 2018 r. o ochronie danych osobowych w związku z zapobieganiem i zwalczaniem przestępczości, prowadzi się w oparciu o odpowiednie przepisy Rozdziału IX Ustawy o ochronie danych osobowych z dnia 10 maja 2018 r. Istotną różnicą są jednak wyłączenia wymienione enumeratywnie, tj. art. 79 ust. 1 pkt. 2, art. 83 ust. 4 oraz art. 85 ww. Ustawy. Wyłączenia te stanowią pole do dyskusji, która nie traci na aktualności, w związku z tym poniżej zostaną one poddane analizie.

Po pierwsze, rzeczoną kontrolę może przeprowadzić jedynie pracownik UODO, a nie członek lub pracownik organu nadzorczego państwa członkowskiego Unii Europejskiej. Jak wskazują P. Liwszic, T. Ochocki i Ł. Pociecha, wyłączenie to uzasadnione jest wzmożoną ochroną danych osobowych zbieranych w celach rozpoznawania, zapobiegania, wykrywania i zwalczania czynów zabronionych ${ }^{8}$. W tym miejscu należy postawić pytanie, jak możliwość wnioskowania organu nadzorczego innego pań-

${ }^{5}$ A także w celu wykonywania kar, w tym ochrony przed zagrożeniami dla bezpieczeństwa publicznego i zapobiegania takim zagrożeniom.

${ }^{6}$ Ustawa o ochronie danych osobowych przetwarzanych $w$ zwiazku z zapobieganiem i zwalczaniem przestępczości. Komentarz. Red. A. Grzelak. Warszawa 2019; P. Liwszic, T. Осноскі, Ł. Росіесна: Ustawa o ochronie danych osobowych przetwarzanych $w$ zwiazku z zapobieganiem i zwalczaniem przestępczości. Komentarz. Warszawa 2019.

7 Także przepisy innych aktów prawnych, np. Ustawy z dnia 16 września 2011 r. o wymianie informacji z organami ścigania państw członkowskich Unii Europejskiej, państw trzecich, agencjami Unii Europejskiej oraz organizacjami międzynarodowymi, t.j. Dz.U. 2018, poz. 484 ze zm., wdrażającej m.in. przepisy dyrektywy w zakresie przekazywania danych osobowych do państw trzecich.

${ }^{8}$ P. LIwszic, T. Осноскі, Ł. PосіесHA: Ustawa o ochronie danych osobowych... 
stwa Unii Europejskiej do Prezesa Urzędu Ochrony Danych Osobowych o przeprowadzenie kontroli w ogranie właściwym mogłaby zagrozić bezpieczeństwu danych osobowych zbieranych w ww. celach. Udzielenie jednoznacznej odpowiedzi nastręcza trudności, szczególnie ze względu na art. 40 dyrektywy Parlamentu Europejskiego ${ }^{9}$, który zakłada przecież międzynarodową współpracę na rzecz ochrony danych osobowych.

Po drugie, w przypadku kontroli przetwarzania danych osobowych dokonywanej przez inspektora Urzędu Ochrony Danych Osobowych - na podstawie art. 55 Ustawy z dnia 14 grudnia 2018 r. o ochronie danych osobowych w związku z zapobieganiem i zwalczaniem przestępczości jego działania niedotyczące wglądu do danych osobowych oraz do innych dokumentów podlegających kontroli, bądź mających bezpośredni związek z przedmiotową kontrolą, mogą odbywać się bez obecności kontrolowanego lub jego upoważnionego przedstawiciela. Przykładem powyższych działań inspektora UODO jest chociażby uzyskanie swobodnego i niekontrolowanego dostępu do pomieszczeń. Opisane powyżej wyłączenie art. 83 ust. 4 Ustawy nie znajduje szerszego uzasadnienia ustawodawcy oraz komentarzy w doktrynie. Z jednej strony wyłączenie to może usprawnić prowadzenie kontroli (jak wskazano w pierwszej części niniejszego artykułu, wymóg stałej obecności kontrolowanego przy wszystkich czynnościach kontroli może stanowić istotne utrudnienie dla jego organizacji). $Z$ drugiej strony jednak nie można tracić z pola uwagi faktu, że już sam tylko dostęp do pomieszczeń może powodować ryzyko dla ochrony danych osobowych, o którą ustawodawca tak zabiegał poprzez wyłączenie art. 79 ust. 1 pkt. 2 Ustawy z dnia 10 maja 2018 r. o ochronie danych osobowych. Perspektywa specyfiki przetwarzanych danych osobowych przez podmioty kontrolowane również nie daje uzasadnienia dla pozbawienia organu nadzorczego możliwości żądania pisemnych lub ustnych wyjaśnień $\mathrm{w}$ trakcie kontroli. To wyłączenie może wręcz w dużym stopniu utrudnić i przedłużyć ustalenie stanu faktycznego. Jeżeli chodzi o trzecie wyłączenie, to w związku z art. 85 Ustawy z dnia 10 maja 2018 r. o ochronie danych osobowych odstapiono od dopuszczenia do utrwalenia przebiegu czynności kontrolnych za pomocą urządzeń rejestrujących obraz lub dźwięk, a także możliwości zwrócenia się do policji o pomoc w przeprowadzeniu kontroli ${ }^{10}$.

9 Dyrektywa Parlamentu Europejskiego i Rady (UE) 2016/680 z dnia 27 kwietnia 2016 r. w sprawie ochrony osób fizycznych w związku z przetwarzaniem danych osobowych przez właściwe organy do celów zapobiegania przestępczości, prowadzenia postępowań przygotowawczych, wykrywania i ścigania czynów zabronionych i wykonywania kar, w sprawie swobodnego przepływu takich danych oraz uchylająca decyzję ramową Rady 2008/977/WSiSW.

${ }^{10}$ Ustawa o ochronie danych osobowych przetwarzanych $w$ zwiazku $z$ zapobieganiem i zwalczaniem przestępczości. Komentarz... 
Należy zwrócić uwagę, że ustawodawca w treści omawianego powyżej przepisu art. 55 posłużył się pojęciem „kontroli przestrzegania przepisów", co zapewne miało odpowiadać kontroli zgodności przetwarzania, która jest jednym z zadań Prezesa Urzędu Ochrony Danych Osobowych. W literaturze wskazuje się, że powyższa różnica wynika ze swoistej niedoskonałości procesu legislacyjnego, a penalizowane zachowania w komentowanym art. 55 dotyczą udaremniania lub istotnego utrudniania kontroli przeprowadzanej na podstawie art. 6 Ustawy z dnia 14 grudnia 2018 r. o ochronie danych osobowych w związku z zapobieganiem i zwalczaniem przestępczości.

W art. 55 Ustawy doprecyzowano pojęcie utrudniania poprzez dodanie wymogu jego istotności. Powyższe działanie ustawodawcy z jednej strony należy ocenić pozytywnie - wynikało bowiem z potrzeby rozróżniania względem organów administracji publicznej. W konsekwencji można wyróżnić utrudnianie zwykłe oraz jego kwalifikowaną wersję - utrudnianie istotne. Zwykłe utrudnianie odnosi się do podmiotów niepodlegających pod Ustawę i jest rozpatrywane na podstawie art. 109 Ustawy z dnia 10 maja 2018 r. o ochronie danych osobowych. Z drugiej jednak strony ustawodawca nie wyjaśnił, jak należy rozumieć ową istotność utrudniania. W praktyce może to powodować problemy ścisłego stosowania powołanego art. 55 Ustawy. Należy zwrócić uwagę, że jako działanie polegające na udaremnianiu lub istotnym utrudnianiu kontrolującemu przeprowadzenia kontroli przepisów może być rozumiane także przyjęcie biernej postawy wobec kontrolującego przeprowadzającego kontrolę, albo na utrudnieniu takich działań, a końcowo na zachowaniu, które całkowicie uniemożliwia przeprowadzenie kontroli. Jeżeli chodzi natomiast o pozostałe elementy określające charakter przestępstwa, to zarówno na gruncie art. 108, jak i art. 55 Ustawy mówi się o przestępstwie skutkowym, materialnym, które może być popełnione tylko umyślnie ${ }^{11}$, gdzie podstawą orzekania są przepisy Kodeksu karnego.

Problematyka kontroli przestrzegania przepisów o ochronie danych osobowych swoje źródło czerpie $\mathrm{w}$ art. $57 \mathrm{RODO}^{12}$. Zgodnie z brzmieniem tego przepisu organ nadzorczy w każdym państwie Unii Europejskiej

11 T. BANAś. W: Ustawa o ochronie danych osobowych..., s. 479; P. BARTA. W: Ustawa o ochronie danych osobowych..., s. 313.

12 K. Kloc. W: Ustawa o ochronie danych osobowych. Komentarz. Red. D. Lubasz. Warszawa 2019 - autor wskazuje, że podstawowym źródłem praw i obowiązków w obszarze ochrony danych osobowych jest art. 51 RODO. Przepis stanowi, że każde państwo członkowskie zapewnia, by za monitorowanie stosowania RODO odpowiadał co najmniej jeden niezależny organ publiczny. Natomiast ściśle do zadań ww. organu nadzorczego odnosi się art. 57 RODO. 
zobowiązany jest do monitorowania i egzekwowania stosowania RODO. Jak wspomniano na wstępie niniejszego artykułu - na gruncie prawa polskiego obowiązek ten jest realizowany przez Prezesa UODO na podstawie art. 78 ust. 1 Ustawy. Przepis ten przyznaje Prezesowi UODO kompetencję do przeprowadzenia z urzędu lub na wniosek kontroli przestrzegania przepisów o ochronie danych osobowych (dalej również jako: kontrola). D. Lubasz ${ }^{13}$ zwraca uwagę na istotny fakt, iż przepisy Ustawy rozszerzają zakres uprawnień do kontroli także innych - niż RODO - aktów prawnych. Chodzi przede wszystkim o te z nich, które stanowią źródło prawa w obszarze ochrony danych osobowych, tj. Ustawę, przepisy wykonawcze oraz właściwe przepisy sektorowe.

Na podstawie art. 78 ust. 2 Ustawy można wyróżnić trzy rodzaje kontroli ${ }^{14}$. Zasadniczym rodzajem jest kontrola planowa, zaś akcesoryjnymi względem niej są kontrola doraźna i wyrywkowa ${ }^{15}$. Kontrola planowa przeprowadzana jest zgodnie z zatwierdzonym przez Prezesa UODO i podanym do wiadomości publicznej planem kontroli sektorowych na dany rok. Plan ten jest ustalany na podstawie zgłaszanych do UODO sygnałów, skarg oraz kierowanych pytań związanych z naruszeniami przepisów o ochronie danych osobowych ${ }^{16}$. Kontrola doraźna nie jest ujęta w rocznym planie kontroli Prezesa UODO. Przeprowadzana jest ona m.in. w przypadku otrzymania przez UODO informacji lub skarg dotyczących domniemanych nieprawidłowości bądź uchybień po stronie administratora danych związanych z przetwarzaniem danych osobowych. Kontrola wyrywkowa natomiast jest sprawowana w ramach monitorowania przez UODO przestrzegania stosowania RODO i obejmuje sektor nieuwzględniony w planie kontroli na rok bieżący.

G. Sibiga zwraca uwagę, że niezależnie od charakteru kontroli jej cel pozostaje wspólny. Jest nim monitorowanie przestrzegania przez administratorów danych przepisów RODO. Należy zauważyć, że w planie kontroli Prezes UODO bezpośrednio i precyzyjnie wskazuje okoliczności prowadzenia kontroli. Jest to zasadnicza różnica w porównaniu ze sta-

13 Ustawa o ochronie danych osobowych. Komentarz. Red. D. LuBASZ...

14 P. Fajgielski: Komentarz do ustawy o ochronie danych osobowych. W: Ogólne rozporzadzenie o ochronie danych. Ustawa o ochronie danych osobowych. Komentarz. Warszawa 2018, s. 73.

15 A. Dмосноwsкa, A. Piotrowska: Ustawa o ochronie danych osobowych. Komentarz. Warszawa 2018.

${ }^{16}$ W okresie od dnia 25 maja 2018 r. do dnia 25 maja 2019 r. do UODO wpłynęło ponad 8000 skarg, dla porównania w ciągu 2017 r. wpłynęło ich 2950, za: S. CzUB-KIEŁCZEWSKa: Dlaczego warto mieć u swojego boku IOD-a, gdy przyjdzie kontroler UODO?. Artykuł opublikowany w dniu 22 lipca 2019 r. na stronie internetowej LEX. Źródło: https://www.lex.pl/udzial-inspektora-ochrony-danych-osobowych-w-kontroli-administra tora-danych-przez-urzad-ochrony-danych-osobowych,625 [dostęp: 10.02.2020]. 
nem prawnym opartym na ustawie o ochronie danych osobowych z dnia 29 sierpnia $1997 \mathrm{r}^{17}$. Wynika ona z obowiązywania i bezpośredniego stosowania RODO jako elementu polskiego porządku prawnego ${ }^{18}$. W związku z powyższym zasadniczym celem kontroli planowej, doraźnej i wyrywkowej jest badanie legalności (in. zgodności z prawem) oraz zgodności istniejącego stanu ze stanem postulowanym przez ustawodawcę (m.in. poprzez analizę dokumentacji, przeprowadzenie rozmów z członkami personelu administratora oraz porównanie ustaleń faktycznych z wymaganiami prawnymi $)^{19}$. Natomiast celem dodatkowym - acz niemniej istotnym - jest formułowanie wniosków, opinii i zaleceń ( $w$ formie protokołu kontroli) dla podmiotu kontrolowanego w przypadku stwierdzenia ewentualnych rozbieżności względem stanu.

Jak czytamy w Sprawozdaniu z działalności Prezesa UODO za 2018 rok $^{20}$, w okresie od dnia 1 stycznia do dnia 24 maja 2018 r. przeprowadzono łącznie 40 (słownie: czterdzieści) kontroli zgodności przetwarzania danych osobowych z przepisami o ochronie danych osobowych. Natomiast w okresie od dnia 25 maja do dnia 31 grudnia 2018 r. przeprowadzono łącznie 32 (słownie: trzydzieści dwie) kontrole przestrzegania przepisów o ochronie danych osobowych. Zatwierdzony przez Prezesa UODO Plan kontroli sektorowych w 2018 r. obejmował głównie tzw. brokerów danych, firmy windykacyjne, instytucje finansowe, stowarzyszenia, a także spółdzielnie i wspólnoty mieszkaniowe (m.in. w zakresie stosowania monitoringu wizyjnego). Kontrole doraźne dotyczyły zaś problematyki wtórnego przetwarzania danych osobowych (m.in. zakupionych baz danych) i podejmowane były na podstawie skarg związanych z realizacją obowiązku informacyjnego przez administratorów danych oraz wykonywania praw podmiotów danych. Plan kontroli sektorowych w 2019 r. ${ }^{21}$ natomiast dotyczył przetwarzania danych osobowych w takich obszarach jak telemarketing, profilowanie $\mathrm{w}$ sektorze bankowym i ubezpieczenio-

17 Ustawa z dnia 27 sierpnia 1997 r. o ochronie danych osobowych, Dz.U. 1997, nr 133, poz. 883 .

${ }^{18}$ M. Kluska. W: Ustawa o ochronie danych osobowych. Komentarz. Red. B. MarcinKowsKI. Warszawa 2018.

19 G. SIBIGA: Postępowanie w sprawach ochrony danych. Warszawa 2003, s. 145.

20 Sprawozdanie z działalności Prezesa UODO za 2018 r. zostało przedstawione Sejmowi Rzeczpospolitej Polskiej, Radzie Ministrów, Rzecznikowi Praw Obywatelskich, Rzecznikowi Praw Dziecka oraz Prokuratorowi Generalnemu, a opublikowane w dniu 6 września 2019 r. w formie załączników na stronie internetowej UODO. Źródło: https:// uodo.gov.pl/437 [dostęp: 10.02.2020].

${ }^{21}$ Plan kontroli sektorowych w 2019 r., opublikowany w dniu 24 stycznia 2019 r. w formie załącznika na stronie internetowej UODO. Źródło: https://uodo.gov.pl/pl/138/ 679 [dostęp: 10.02.2020]. 
wym, system identyfikacji i monitoringu odpadów. Podobnie jak w 2018 r. uwaga UODO będzie skupiona na weryfikacji jednostek administracji publicznej, ale także na Policji, Straży Granicznej, aresztów śledczych oraz danych udostępnianych w Biuletynie Informacji Publicznej przez podmioty do tego zobowiązane. Jeżeli chodzi o akcesoryjne rodzaje kontroli, to ww. sprawozdanie nie traktuje o nich.

Plan kontroli opublikowany w styczniu 2020 r. $^{22}$ stanowi kontynuację działań prowadzonych przez Prezesa UODO w 2019 r. oraz jest odpowiedzią na zagrożenia naruszenia przepisów o ochronie danych osobowych i aktualne zainteresowanie społeczne konkretnymi problemami. Tegoroczny plan kontroli zakłada bowiem weryfikację sektora bankowego (pod kątem sporządzania kopii, skanów dokumentów tożsamości klientów i potencjalnych klientów), podmiotów korzystających z systemu zdalnego odczytu wodomierzy (tzw. inteligentne liczniki) oraz organów przetwarzających dane osobowe w Systemie Informacyjnym Schengen i Wizowym Systemie Informacyjnym (tj. w konsulatach i administracji skarbowej $)^{23}$.

Przestępstwo utrudniania lub udaremniania kontroli prowadzonej przez organ nadzorczy, o którym mowa w przedmiotowym art. 108 Ustawy, nie stanowi novum w polskim prawie karnym. Art. 54a uprzednio obowiązującej Ustawy z dnia 29 sierpnia 1997 r. o ochronie danych osobowych regulował ten problem ${ }^{24}$. Zasadniczą różnicą było jednak to, że czynność sprawcza miała być zrealizowana w stosunku do „kontrolującego”, a nie „inspektora”, a znamię w postaci „czynności kontrolnej” zostało zastąpione znamieniem „kontroli przestrzegania przepisów o ochronie danych osobowych". Powyższe prowadzi do wniosku, że wraz z nowelizacją przepisów o ochronie danych osobowych celem ustawodawcy było zapewnienie skuteczności systemu ochrony danych osobowych ${ }^{25}$. Art. 108 Ustawy penalizuje zachowanie osoby fizycznej, która udaremnia bądź utrudnia prowadzenie kontroli. Przestępstwo to ma charakter powszechny, co oznacza, że krąg sprawców nie jest ograniczony.

Podmiot przestępstwa art. 108 Ustawy został określony przez ustawodawcę abstrakcyjnie, za pomocą zaimka „kto”. Warto wskazać, że jest to najczęstszy sposób formułowania ustawowych znamion przestępstw

22 Plan kontroli sektorowych w 2020 r., opublikowany w dniu 2 stycznia 2020 r., na stronie internetowej UODO. Źródło: https://uodo.gov.pl/pl/138/1302 [dostęp: 10.02.2020].

${ }_{23}$ Na podstawie przepisów Ustawy z dnia 24 sierpnia 2007 r. o udziale Rzeczpospolitej Polskiej w Systemie Informacyjnym Schengen i Wizowym Systemie Informacyjnym, Dz.U. 2019, poz. 1844.

24 Dz.U. 1997, nr 133, poz. 883.

${ }^{25}$ Uzasadnienie z dnia 5 maja 2018 r. do projektu ustawy o ochronie danych osobowych (Druk Sejmowy nr 2410, Sejm VIII kadencji), s. 48. 
powszechnych. Jak wskazuje P. Fajgielski, dotyczy on przede wszystkim każdego, kto powinien ułatwiać kontrolę lub co najmniej jej nie utrudniać ${ }^{26}$. Za sprawcę czynu $\mathrm{z}$ art. 108 Ustawy może być uznany zatem nie tylko kontrolowany lub osoba upoważniona do reprezentowania go w toku kontroli (np. członek zarządu lub członek personelu), ale także inna osoba, nawet niezwiązana z kontrolowanym stosunkiem podległości służbowej bądź organizacyjnej. W literaturze podkreśla się, że osobom z tej ostatniej kategorii trudno jest wykazać winę ${ }^{27}$. Omawiane przestępstwo może być popełnione bowiem wyłącznie umyślnie. Odpowiedzialności karnej podlega nie tylko sprawca (w tym sprawca kierowniczy lub polecający) i współsprawca przestępstwa, ale także podżegacz lub pomocnik (art. 18 k.k.), a odpowiedzialność określona w komentowanym przepisie obejmuje również usiłowanie (art. 13 k.k.). Sprawca może działać z zamiarem bezpośrednim (tj. mieć zamiar popełnienia czynu i chcieć go popełnić) lub z zamiarem ewentualnym (tj. tylko przewidywać możliwość popełnienia tego czynu zabronionego i godzić się na to). Skuteczne postawienie zarzutu popełnienia przestępstwa wymaga zatem wykazania umyślności działania sprawcy.

Podstawą analizy przedmiotu ochrony art. 108 Ustawy są przepisy Rozdziału IX Ustawy - art. od 78 do 91, które stanowią o zasadach prowadzenia kontroli przestrzegania przepisów o ochronie danych osobowych. Szczególnie istotny jest art. 84 ust. 1 Ustawy, określający katalog uprawnień przysługujących kontrolującemu. Niemożliwość lub ograniczenie możliwości ich realizacji będzie stanowić realizację znamion czynu $\mathrm{z}$ art. 108 Ustawy. Co do zasady kontrolę przeprowadzają upoważnieni przez Prezesa UODO pracownicy UODO oraz ewentualnie personel organu nadzorczego państwa członkowskiego Unii Europejskiej uczestniczący we wspólnych operacjach nadzorczych. Bezpośrednim przedmiotem ochrony jest właściwe i niezakłócone wykonywanie czynności służbowych przez te osoby. Należy zwrócić uwagę, że czynności kontrolne mogą być również wykonywane przez osoby posiadające wiedzę specjalistyczną, które mogą zostać „przybrane” przez kontrolującego do pomocy, jeżeli przeprowadzenie czynności kontrolnych wymaga takiej wiedzy. Osoby takie mogą, zgodnie z art. 82 Ustawy, uczestniczyć w kontroli jako zewnętrzni eksperci, niebędący pracownikami UODO, którzy współuczest-

${ }^{26}$ P. FAJGIELSKI: Komentarz do ustawy o ochronie danych osobowych. W: Ogólne rozporządzenie o ochronie danych. Ustawa o ochronie danych osobowych. Komentarz. Warszawa 2018.

27 A. BŁachNio-PARZYCH: Prawnokarna ochrona inspektora ochrony danych osobowychprzestępstwo udaremnienia lub utrudnienia kontroli przestrzegania przepisów o ochronie danych osobowych. W: Nowelizacja ustawy o ochronie danych osobowych 2010. Red. G. SiBIGA. MoP 2011, nr 3, dodatek specjalny, s. 37. 
niczą $\mathrm{w}$ procedurze kontroli ${ }^{28}$. W konsekwencji za uboczny przedmiot ochrony należy uznać właściwe i niezakłócone wykonywanie czynności kontrolnych przez osoby posiadające wiedzę specjalistyczną, które mogą zostać przybrane przez kontrolującego do pomocy, jeżeli przeprowadzenie czynności kontrolnych wymaga takiej wiedzy.

Dla zobrazowania relacji pomiędzy bezpośrednim a ubocznym przedmiotem ochrony można posłużyć się przykładem kontroli przetwarzania danych $\mathrm{w}$ systemach informatycznych. Jeżeli kontrolę taką prowadzi pracownik UODO wraz z ekspertem z zakresu IT, znamiona czynu $\mathrm{z}$ art. 108 Ustawy zostaną wypełnione również wtedy, gdy działania lub zaniechania kontrolowanego dotyczyć będą ww. eksperta (np. gdy nie zostanie on wpuszczony na teren przedsiębiorstwa pomimo posiadania ważnego upoważnienia). Co do zasady katalog uprawnień z art. 84 ust. 1 Ustawy odnosi się przede wszystkim do pracownika UODO posiadającego legitymację służbową (tzw. legitymację inspektorską) ${ }^{29}$. Natomiast fakt, iż ekspert współuczestniczący w kontroli nie posiada ww. legitymacji, nie usprawiedliwia utrudniania przez kontrolowanego przeprowadzenia czynności kontrolnych. Działając na podstawie i w zakresie nadanego przez UODO upoważnienia, ekspert ma bowiem prawo podejmować czynności kontrolne na równi z pracownikiem UODO. W związku z tym postawienie kontrolowanemu zarzutu $\mathrm{z}$ art. 108 Ustawy może być $\mathrm{w}$ takim przypadku zasadne. Czynności kontrolne realizowane na podstawie upoważnienia, bez legitymacji służbowej, nie wpływa na zakres ochrony uprawnień $\mathrm{z}$ art. 84 ust. 1 i 2 Ustawy oraz nie wyłącza odpowiedzialności na gruncie art. 108 Ustawy.

Na gruncie art. 84 ust. 2 Ustawy kontrolowany ma obowiązek zapewnienia osobom upoważnionym do udziału w kontroli warunków i środków niezbędnych do sprawnego prowadzenia kontroli, sporządzania kopii lub wydruków dokumentów i informacji zgromadzonych na nośnikach, urządzeniach i w systemach kontrolowanego. Utrudnianie dostępu do pomieszczeń, niezapewnienie warunków do prowadzenia kontroli, odmowa udostępnienia dokumentów czy informacji zgromadzonych na nośnikach i systemach cyfrowych będzie zatem wypełniać znamiona czynu opisanego w art. 108 Ustawy.

28 A. Dмосноwsкa, A. Piotrowska: Ustawa o ochronie danych osobowych..., s. 129.

${ }_{29}$ Zgodnie z art. 47 Ustawy Rada Ministrów określa, w drodze rozporządzenia, wzór legitymacji służbowej pracownika UODO. Jak deklaruje UODO na swojej stronie internetowej, w przypadku wątpliwości co do wiarygodności osoby, która okaże dokumenty upoważniające do kontroli, istnieje możliwość telefonicznego zweryfikowania, czy rzeczywiście jest tą osobą, za którą się podaje, i jest upoważniona przez Prezesa UODO do przeprowadzenia kontroli. 
Mając na uwadze fakt, że przepisy nie definiują pojęć „utrudniania” i „udaremniania” kontroli, dokonując ich wykładni, należy odwołać się w pierwszej kolejności do wykładni językowej. Według słownika języka polskiego PWN „udaremniać” oznacza tyle co sprawiać, że coś nie zostaje zrealizowane, natomiast „utrudniać” to stanowić lub sprawiać przeszkody. Trzeba poprzeć stanowisko wyrażone przez P. Fajgielskiego, iż aktualne pozostają ustalenia poczynione na gruncie art. 54a ustawy $\mathrm{z}$ dnia 29 sierpnia 1997 r. $^{30}$, zgodnie z którym przy interpretacji pojęć „udaremnianie” i „utrudnianie” można odwołać się do dorobku doktryny prawa karnego, ukształtowanego na gruncie art. 225 k.k. W tym zakresie literatura przedmiotu ${ }^{31}$ wskazuje, że udaremnianie lub utrudnianie kontroli może polegać m.in. na niewpuszczeniu na dany teren osób zamierzających przeprowadzić kontrolę, zniszczeniu, ukryciu, uszkodzeniu, usunięciu lub uczynieniu bezużytecznymi dokumentów, które kontrolujący mają zbadać, uniemożliwieniu pobrania próbek, jak również niedopuszczeniu do pewnych materiałów, urządzeń lub pomieszczenia, udzielaniu nieprawdziwych informacji lub też odmowie udzielenia informacji, a także na odmowie złożenia zeznań osobie uprawnionej do przeprowadzenia kontroli, niewykonaniu żądania kontrolującego, które zgodnie z przepisami o danej kontroli może on wysunąć wobec podmiotu kontrolowanego.

Jeżeli natomiast chodzi o orzecznictwo wyrażane na gruncie innych regulacji prawnych, adekwatne wydaje się stanowisko Sądu Najwyższego, który w uzasadnieniu postanowienia dotyczącego kontroli podatkowej potwierdził opisaną powyżej zależność, zgodnie z którą pojęcie „utrudniania" rozumie się jako bezprawne stworzenie przeszkody dla przeprowadzanej czynności służbowej, natomiast „udaremnianie” to bezprawne uniemożliwienie jej przeprowadzenia ${ }^{32}$.

Rozpatrując znaczenie pojęć „utrudniania” i „udaremniania” na gruncie kontroli przestrzegania przepisów o ochronie danych osobowych, przez udaremnianie kontroli należy rozumieć uniemożliwianie osiągnięcia jej celu, za który zasadne wydaje się przyjęcie przeprowadzenia kontroli w zakresie wynikającym z upoważnienia. „Utrudnianie” oznaczać będzie stwarzanie przeszkód w swobodnym wykonywaniu przez kontrolującego przysługujących mu uprawnień lub niewykonywanie obowiązków przez osobę zobowiązaną, co jednak obiektywnie nie uniemożliwia prowadzenia kontroli. Utrudnianie jest zatem łagodniejszą formą przestępstwa, a jego skutki mają znacznie mniejszy wpływ na możliwość realizacji uprawnień kontrolującego.

30 Dz.U. 1997, nr 133, poz. 883.

31 M. Jachimowicz: Przestępstwo zakłócania kontroli (art. 225 k.k.). Prok. i Pr. 2008, nr 7-8, s. 42.

${ }^{32}$ Post. SN z dnia 20 lutego 2014 r., V KK 398/13. 
Na podstawie art. 84 Ustawy kontrolującemu przysługuje prawo do: wstępu w godzinach od 6:00 do 22:00 na grunt oraz do budynków, lokali lub innych pomieszczeń, wglądu do dokumentów i informacji mających bezpośredni związek z zakresem przedmiotowej kontroli, przeprowadzania oględzin miejsc, przedmiotów, urządzeń, nośników oraz systemów informatycznych lub teleinformatycznych służących do przetwarzania danych, żądania złożenia pisemnych lub ustnych wyjaśnień oraz przesłuchiwania, zlecania sporządzania ekspertyz i opinii, utrwalania w uzasadnionych przypadkach przebiegu kontroli lub poszczególnych czynności przy pomocy urządzeń rejestrujących obraz lub dźwięk. Kontrolowany tymczasem zobowiązany jest do: zapewnienia kontrolującemu oraz osobom upoważnionym do udziału w kontroli warunków i środków niezbędnych do sprawnego przeprowadzenia kontroli (w tym sporządzania we własnym zakresie kopii lub wydruków dokumentów oraz informacji zgromadzonych na nośnikach, w urządzeniach lub systemach informatycznych), potwierdzania za zgodność z oryginałem sporządzonych kopii lub wydruków, przedkładania na żądanie kontrolującego tłumaczenia na język polski sporządzonej w języku obcym dokumentacji (sporządzonego na koszt własny) oraz udostępniania kontrolującym informacji objętych tajemnicą prawnie chronioną ${ }^{33}$.

Powyższe wyliczenie obrazuje szeroki zakres uprawnień, jakie przyznano kontrolującemu, oraz odpowiadających im obowiązków kontrolowanego. Analiza tego rodzaju korelacji w kontekście odpowiedzialności $\mathrm{z}$ art. 108 Ustawy prowadzi do wniosku, że skuteczne postawienie zarzutu utrudniania lub udaremniania kontroli wymagać będzie przede wszystkim wykazania oskarżonemu umyślnego i bezprawnego ograniczenia ww. praw lub niewywiązania się z ww. obowiązków. Podstawowymi obowiązkami kontrolowanego są: zapewnianie kontrolującemu warunków i środków niezbędnych do sprawnego przeprowadzenia kontroli, przedkładanie żądanych dokumentów i materiałów oraz terminowe udzielanie informacji i dostępu do miejsc przetwarzania danych. Co do zasady powyższe obowiązki winny być dopełniane niezwłocznie, niemniej jednak uzasadnione opóźnienie nie powinno zostać automatycznie uznane za wypełnienie znamion czynu z art. 108 Ustawy.

Przestępstwo utrudniania lub udaremniania kontroli jest przestępstwem skutkowym. Oznacza to, że nie każde zachowanie wpływające negatywnie na realizację praw kontrolującego zostanie automatycznie uznane za wypełniające znamiona tego czynu. Za przestępstwo uznać należy takie działania lub zaniechania, które jednoznacznie wywierają co najmniej istotny wpływ na kontrolę. Ocena w tym przedmiocie bę-

\footnotetext{
33 Art. 64 i 65 w zw. z art. 91 Ustawy.
} 
dzie zależna od obiektywnego wpływu danego zachowania na proces kontroli. Wracając do przytoczonego wcześniej przykładu, można zatem postawić tezę, że nieprzedłożenie przez zobowiązanego w terminie żądanych dokumentów nie będzie stanowiło przestępstwa utrudniania kontroli, gdy osoba ta bez zbędnej zwłoki wyjaśni kontrolującemu uzasadnioną okolicznościami przyczynę opóźnienia. Wedle tych samych zasad należy rozpatrywać wszystkie pozostałe działania ograniczające w jakiś sposób realizację uprawnień kontrolującego. Nie będzie zatem oczywista karalność działań związanych z ograniczeniem kontrolującemu dostępu do budynków lub pomieszczeń kontrolowanego przedsiębiorstwa, jeśli w danej sytuacji działanie to uzasadniają okoliczności. Swoboda wstępu i poruszania się kontrolowanego po terenie kontrolowanego przedsiębiorstwa nie jest bezwarunkowa. W doktrynie wskazuje się między innymi, że ograniczają ją przede wszystkim ramy konstytucyjne, takie jak wyrażony w art. 51 Konstytucji Rzeczpospolitej Polskiej ${ }^{34}$ zakaz pozyskiwania informacji i danych dotyczących obywateli w zakresie wykraczającym poza niezbędny w demokratycznym państwie prawnym. Kontrolujący ma zatem prawo do wstępu do budynków i pomieszczeń kontrolowanego wyłącznie $\mathrm{w}$ takim zakresie, jaki jest niezbędny do przeprowadzenia kontroli i wskazany w imiennym upoważnieniu ${ }^{35}$. Z drugiej strony warto zauważyć, że karalność działania polegającego na odmowie wstępu do pomieszczeń kontrolowanego, w zakresie, w jakim żądanie kontrolującego odpowiada jego uprawnieniom, nie wymaga, aby była ona połączona ze stosowaniem przemocy lub groźby bezprawnej ${ }^{36}$. W kontekście odpowiedzialności karnej z tytułu art. 108 Ustawy istotny jest sam efekt danego działania, a nie jego forma.

Celem uzupełnienia prowadzonego wywodu należy wyjaśnić, że pomimo uregulowania kwestii karnych związanych z ochroną danych osobowych poza Kodeksem karnym odpowiedzialność z tytułu art. 108 Ustawy podlega ograniczeniom wynikającym z ogólnych zasad Kodeksu karnego dotyczących wyłączenia odpowiedzialności. Zastosowanie znajdą zatem m.in. przepisy dotyczące błędu co do znamion (art. 28 k.k.), błędu co do okoliczności wyłączającej bezprawność lub winę (art. 29 k.k.), nieświadomości bezprawności (art. 30 k.k.) oraz niepoczytalności (art. 31 k.k.).

Źródła dostępne na dzień przygotowania niniejszego artykułu uniemożliwiają opis i analizę zasadniczych problemów w prowadzeniu kon-

${ }^{34}$ Dz.U. 1997, nr. 78, poz. 483.

35 P. Litwiński. W: P. BARTA, P. Litwiński: Ustawa o ochronie danych osobowych. Komentarz. Wyd. 4. Warszawa 2016, s. 162.

${ }_{36}$ M. BŁaChNIO-PARZYCH: Prawnokarna ochrona inspektora ochrony danych osobowychprzestępstwo udaremnienia lub utrudnienia kontroli przestrzegania przepisów o ochronie danych osobowych. MoP 2011, nr 3, dodatek specjalny. 
troli przez UODO. W sprawozdaniu z działalności Generalnego Inspektora Ochrony Danych Osobowych [dalej jako: GIODO] ${ }^{37}$ wskazano, że ówcześnie zasadniczym problemem był brak współpracy podmiotu kontrolowanego. Najczęściej wskazywanymi przykładami utrudniania lub udaremniania czynności kontrolnych były m.in. odmowa wstępu do pomieszczenia, w którym zlokalizowany jest zbiór danych, oraz do pomieszczenia, w którym przetwarzane są dane poza zbiorem danych, odmowa udostępnienia dokumentów zawierających dane osobowe, nieodbieranie korespondencji kierowanej do kontrolowanego przez GIODO oraz pozostawienie bez odpowiedzi korespondencji odebranej, nieodbieranie połączeń telefonicznych wykonywanych przez GIODO na właściwy numer telefonu kontaktowego oraz wskazanie błędnego numeru telefonu kontaktowego, np. na stronie internetowej, ogólne trudności w umówieniu spotkania z osobami uprawnionymi do reprezentacji kontrolowanego, nieuzasadnione wydłużanie czasu oczekiwania na osoby dysponujące wiedzą o procesie przetwarzania danych osobowych w celu przyjęcia od nich ustnych wyjaśnień do protokołu, nieuzasadnione wydłużanie czasu oczekiwania na dokumenty mające bezpośredni związek z przedmiotem kontroli, odmowa okazania dokumentów i udzielenia informacji oraz udzielanie nieprawdziwych informacji lub okazywanie niewłaściwych dokumentów, odmowa złożenia zeznań osobie uprawnionej do przeprowadzania kontroli. Ocena zasadności postawienia w ww. przypadkach zarzutu utrudniania prowadzenia kontroli wymagałaby jednak analizy wszystkich omówionych w niniejszym artykule okoliczności konkretnych sytuacji oraz ich wpływu na możliwość prowadzenia kontroli. Warto zwrócić uwagę, że przykłady wskazane powyżej charakteryzują się uniwersalnością, a zatem nie tracą na aktualności.

Kontrola przestrzegania przepisów o ochronie danych osobowych nie pozostaje bez negatywnego wpływu na funkcjonowanie przedsiębiorstwa kontrolowanego. $\mathrm{Z}$ punktu widzenia przedsiębiorcy istotne jest, aby czas, w którym będzie prowadzona kontrola, zaplanować w taki sposób, żeby pracownicy w jak najmniejszym stopniu zostali wyłączeni ze swoich obowiązków służbowych (np. ze względu na uczestnictwo w przesłuchaniach lub przygotowywaniu dokumentów dla kontrolującego). Jednocześnie należy pamiętać, że utrudnianie czynności kontrolnych nie spowoduje odstąpienia od kontynuowania kontroli i najprawdopodobniej nie zapobiegnie ujawnieniu ewentualnych nieprawidłowości, a może pociągać za sobą znaczące, negatywne konsekwencje prawne. Jednym z zalecanych w takiej sytuacji środków ostrożności jest skorzystanie z usług profesjo-

37 Sprawozdanie z działalności Generalnego Inspektora Ochrony Danych Osobowych w roku 2015. Źródło: http://www.giodo.gov.pl/data/filemanager_pl/sprawozdaniaroczne/2015.pdf [dostęp: 10.02.2020]. 
nalnych doradców. Posiadane przez nich wiedza i doświadczenie pomogą usprawnić przebieg kontroli oraz prawidłowo zabezpieczyć interesy kontrolowanego.

W ciągu kilku ostatnich lat nastąpił znaczący rozwój prawodawstwa w zakresie ochrony danych osobowych (m.in. omawiana w niniejszym artykule Ustawa z dnia 10 maja 2018 r. o ochronie danych osobowych oraz Ustawa z dnia 14 grudnia 2018 r. o ochronie danych osobowych w związku z zapobieganiem i zwalczaniem przestępczości). Co więcej, właśnie w 2020 r. upływa dwuletni okres obowiązywania znowelizowanych przepisów o ochronie danych osobowych. Zdaje się, że jest to wystarczający przedział czasu dla oceny miarodajności i efektywności konkretnych przepisów, a także zbadania problematyki kontroli UODO.

Warto bowiem, aby utrzymana została tendencja, w której wspólnym mianownikiem jest nie tylko ochrona praw jednostki przed zagrożeniami związanymi z nieograniczonym przetwarzaniem danych na jej temat, ale także harmonizacja i usprawnienie praktyki badania zgodności stosowanych przepisów właśnie $\mathrm{w}$ ramach czynności kontrolnych opisywanych w art. 108 Ustawy z dnia 10 maja 2018 r. o ochronie danych osobowych oraz Ustawy z dnia 14 grudnia 2018 r. o ochronie danych osobowych w związku z zapobieganiem i zwalczaniem przestępczości stosowanych w praktyce.

Uwzględniając zakres czynności kontrolnych przeprowadzonych przez pracowników UODO w latach ubiegłych (m.in. w 2018 i 2019 r.), wnioski z nich płynące mogą być podstawą do analizy relacji pomiędzy kontrolowanym a kontrolującym.

\section{Bibliografia}

\section{Literatura}

Banaś T. W: Ustawa o ochronie danych osobowych. Komentarz. Red. B. MarcinKowsKi. Warszawa 2018.

Barta P. W: Ustawa o ochronie danych osobowych. Komentarz. Red. B. Marcinкоwsкi. Warszawa 2018.

BeACHNio-PARZYCH M.: Prawnokarna ochrona inspektora ochrony danych osobowych - przestępstwo udaremnienia lub utrudnienia kontroli przestrzegania przepisów o ochronie danych osobowych. MoP 2011, nr 3, dodatek specjalny.

Dмосношsкa A., Piotrowska A.: Ustawa o ochronie danych osobowych. Komentarz. Warszawa 2018.

FAJGIELSKI P.: Komentarz do ustawy o ochronie danych osobowych. W: Ogólne rozporzadzenie o ochronie danych. Ustawa o ochronie danych osobowych. Komentarz. Warszawa 2018.

Jachimowicz M.: Przestępstwo zakłócania kontroli (art. 225 k.k.). Prok. i Pr. 2008, nr 7-8. 
Kloc K. W: Ustawa o ochronie danych osobowych. Komentarz. Red. D. Lubasz. Warszawa 2019.

KlusKa M. W: Ustawa o ochronie danych osobowych. Komentarz. Red. B. MarciNKOWSKI. Warszawa 2018.

LITWIŃsKi P. W: P. BARTA, P. LITWIŃsKi: Ustawa o ochronie danych osobowych. Komentarz. Wyd. 4. Warszawa 2016.

Liwszic P., Oсноскі T., Pociecha Ł.: Ustawa o ochronie danych osobowych przetwarzanych $w$ związku z zapobieganiem i zwalczaniem przestępczości. Komentarz. Warszawa 2019.

Ustawa o ochronie danych osobowych przetwarzanych $w$ zwiazku z zapobieganiem i zwalczaniem przestępczości. Komentarz. Red. A. GrzelaK. Warszawa 2019.

\section{Akty prawne}

Ustawa z dnia 27 sierpnia 1997 r. o ochronie danych osobowych, Dz.U. 1997, nr 133, poz. 883 .

Dyrektywa Parlamentu Europejskiego i Rady (UE) 2016/680 z dnia 27 kwietnia 2016 r. w sprawie ochrony osób fizycznych w związku z przetwarzaniem danych osobowych przez właściwe organy do celów zapobiegania przestępczości, prowadzenia postępowań przygotowawczych, wykrywania i ścigania czynów zabronionych i wykonywania kar, w sprawie swobodnego przepływu takich danych oraz uchylająca decyzję ramową Rady 2008/977/WSiSW.

Rozporządzenie Parlamentu Europejskiego i Rady (UE) 2016/679 z dnia 27 kwietnia 2016 r. w sprawie ochrony osób fizycznych w związku z przetwarzaniem danych osobowych i w sprawie swobodnego przepływu takich danych oraz uchylenia dyrektywy 95/46/WE (ogólne rozporządzenie o ochronie danych).

\section{Orzecznictwo}

Post. SN z dnia 20 lutego 2014 r., V KK 398/13.

\section{Źródła internetowe}

Czub-KieŁczewska S.: Dlaczego warto mieć u swojego boku IOD-a, gdy przyjdzie kontroler UODO?. Artykuł opublikowany w dniu 22 lipca 2019 r. na stronie internetowej LEX. Źródło: https://www.lex.pl/udzial-inspektora-ochrony-da nych-osobowych-w-kontroli-administratora-danych-przez-urzad-ochronydanych-osobowych,625 [dostęp: 10.02.2020].

Sprawozdanie z działalności Generalnego Inspektora Ochrony Danych Osobowych w roku 2015. Źródło: http://www.giodo.gov.pl/data/filemanager_pl/spra wozdaniaroczne/2015.pdf [dostęp: 10.02.2020].

\section{Źródła inne}

Uzasadnienie z dnia 5 maja 2018 r. do projektu ustawy o ochronie danych osobowych (Druk Sejmowy nr 2410, Sejm VIII kadencji). 